\title{
On Guidelines for College English Teaching and Challenges for College English Teachers
}

\author{
Huiyin $\mathrm{Li}^{1}$ \\ ${ }^{1}$ School of English and Education, Guangdong University of Foreign Studies, China \\ Correspondence: Huiyin Li, School of English and Education, Guangdong University of Foreign Studies, China. \\ E-mail: clara2006@126.com
}

Received: November 1, 2015 Accepted: December 8, 2015 Online Published: December 9, 2015

doi:10.5539/elt.v9n1p77

URL: http://dx.doi.org/10.5539/elt.v9n1p77

\begin{abstract}
This article performs an exploratory study of the newly formulated Guidelines for College English Teaching (Draft Exposure)(2015)(Guidelines), aiming at exploring how different the latest Guidelines is from the previous ones, what challenges it brings to teachers and how these challenges can be countered. Therefore, comparisons are made among six syllabi to illustrate the developments college English has achieved and its existent problems as well. To address these problems, Guidelines (2015) is issued with three new features: the integration of instrumentality and humanity, the introduction of intercultural education and the system of multiple curriculum for multiple teaching objectives. Its issuing poses tremendous challenges to college English teachers, of which increasing demands on college English teachers' professional expertise, skillful employment of information technology and academic performance stand out. To help counter these challenges and difficulties, suggestions are made from three levels with the hope that improved teachers' quality can facilitate the implementation of Guidelines (2015) and guarantee the potential achievement of its expected objectives. These suggestions are: life-long learning and self-directed development consciousness, the establishment of teacher education system by faculties and universities and continued governmental support in and favorable policies to college English teacher education.
\end{abstract}

Keywords: college English, syllabus, instrumentality and humanity, intercultural education

\section{Introduction}

English has enjoyed great favor and fervor in China since the execution of Open Policy in 1978. The craze and enthusiasm in English learning is unquestionably connected with potential benefits English can offer to its learners. On a national dimension, English, as an international language in foreign exchanges, is regarded as playing a crucial role in national modernization and development. As Hu (2005) observes that "since China embarked on its modernization drive, policy statements and mass media have constructed a discourse that has linked national English proficiency and socioeconomic development. The discourse has fundamentally shaped the ethos of Chinese society" (p. 28). On an individual dimension, English is a passport to career advancement and prosperous personal development. People use English for upward social mobility, with English tests unanimously required for access to and exit from universities, for job-hunting and career promotion, and for the chance to go abroad (Liu, 2015). Because of its unique status and prospects it can bring, great efforts and resources have been invested in English language education, both personally and officially.

As the main force of China's development, all college and university students (non-English majors) are required to study English for at least one year (It varies. In some universities, students have to learn two or three years). During the undergraduate period, students have to get required credits in English, pass not only all English achievement tests held by colleges and universities, but the national CET4 or CET6 (CET stands for College English Test; CET 6 is a higher level than CET 4 and both are held twice a year) held by the Ministry of Education. After satisfying all the requirements, students can obtain their bachelor degrees.

All English courses non-English major undergraduates take are called College English (CE). As an obligatory course, it has the largest number of students and wide-spread influence, which can never be superseded by any other courses. As a language foundation course, CE used to be named as Public English or General English. Usually it is carried out via Intensive Reading (used to be called so as it focuses on the intensive comprehension of texts), or Comprehensive English (because it includes the training of the skills in listening, speaking, reading, 
writing and translating) or Integrated English (means this course integrates the five skills mentioned above). All these three courses are basically the same, with a focus on reading and helping improve students' other four basic skills in the meanwhile. Until most recently CE has both compulsory and optional courses, such as Chinese Culture and Cross-cultural Communication, which are aimed to improve learners' cultural awareness and communicating competence. In all, it is a basic but core course all students care and have to attach importance to as it decides their diploma and furthermore, their advancement in the future. Naturally, it is a most controversial topic in higher education and more susceptible to change and reform.

As the newly issued document on CE teaching in China, Guidelines (2015) is yet to be studied in China. Although syllabus is not extensively studied by researchers in China, this article attempts to offer an exploratory study of Guidelines to illustrate its three new features by comparison and induction methods. To do so, a chronological account of CE syllabi is first presented from the 1960s till today, showcasing the changes and different foci at each phase. After making the comparison among CE syllabi at different phases, the article points out the challenges for $\mathrm{CE}$ teachers posed by Guidelines. As the initiators and implementers, CE teachers decide how Guidelines can be carried out and to what degree CE in China can achieve its expected success. Therefore, suggestions are proposed as a feasible solution to confront those challenges in the end.

\section{Brief Review of Previous Syllabi for College English}

College English used to be named as Public English till 1985. By 1956, Public English was consecutively established in colleges and universities, and officially recognized as the first foreign language in the 1960s (Liu, 2015). But its development came to a standstill during the Cultural Revolution Period between 1966 and 1977. Therefore, during the initial few years after Cultural Revolution, college students started their English learning from the scratch, that is, with alphabet study.

The rise of English was greatly facilitated and catalyzed by the issuing and revising of English curriculum syllabus. To guarantee expected success of English learners, CE syllabus was developed and modified again and again to meet requirements for talents due to economic development.

Syllabus is defined by different researchers with different expressions but with similar ideas. Chung and Kim (2014) define syllabus as a blueprint of course created by an exam board or professors who supervise or control course quality to introduce the teaching course and provide useful information and learning materials. Wilkins (1981) proposes that syllabuses are specifications of the content of language teaching which have been submitted to some degrees of structuring and ordering with the aim of making teaching and learning a more effective process. He emphasizes that content in his definition includes both linguistic and non-linguistic categories. According to Dublin and Olshtain (1986), a syllabus is a document which ideally describes what learners are expected to know at the end of the course, what is to be taught or learned during the course, when to be taught, how to be taught and how to be evaluated. C E syllabus in China is basically formulated in this mode.

Among the functions syllabus performs, one is syllabus can influence teaching effectiveness (Bryan, Tracy, \& Allison, 2010). In Chinese context, CE syllabus is a policy document that provides nationwide policy guidance to $\mathrm{CE}$ teachers. Syllabus to teaching is the baton to performers. It helps teachers in teaching, selecting and compiling textbooks and evaluating students. Thus, an understanding of CE syllabus enables teachers to instruct textbooks and handle classes in a more sensible way, to achieve desired teaching effect in a more efficient way and to design their own specific and practical syllabus for their courses in an easier way.

For nearly 6 decades, CE syllabus has witnessed tremendous changes and contributed to gratifying progress. At the same time, it also encounters unprecedented problems and challenges. The following chart offers an overview of six CE curriculum syllabi, displaying the changes in both contents and times: 
Table 1. Comparison of different CE syllabi

\begin{tabular}{|c|c|c|c|c|c|c|}
\hline Times & 1962 & 1980 & 1986 & 1999 & 2004 & 2007 \\
\hline $\begin{array}{l}\text { Vocabulary } \\
\text { (words) }\end{array}$ & \multicolumn{2}{|l|}{1400} & $\mid \begin{array}{l}3800-4000 \quad \text { (for } \\
\text { basic level ) } \\
5000-5300 \quad \text { (for } \\
\text { higher level ) }\end{array}$ & $\begin{array}{l}4200 \text { (basic requirement ) } \\
5500 \text { (higher requirement ) }\end{array}$ & $\begin{array}{l}4500 \quad \text { basic } \\
\text { requirement) } \\
5500 \text { (intermediate } \\
\text { requirement) } \\
6500 \text { (advanced } \\
\text { requirement) }\end{array}$ & $\begin{array}{l}4795 \quad \text { (basic } \\
\text { requirement) } \\
6395 \\
\text { (intermediate } \\
\text { requirement) } \\
7675 \\
\text { (advanced } \\
\text { requirement) }\end{array}$ \\
\hline Grammar & \multicolumn{2}{|l|}{ emphasized } & \multicolumn{2}{|c|}{ Mentioned, but not emphasized } & \multicolumn{2}{|l|}{ Not mentioned } \\
\hline Reading & $\begin{array}{l}\text { Emphasized } \\
\text { scientific } \\
\text { reading ability }\end{array}$ & $\begin{array}{l}\text { Emphasized } \\
\text { reading ability }\end{array}$ & $\begin{array}{l}\text { A high level of } \\
\text { reading ability }\end{array}$ & $\begin{array}{l}\text { Reading ability should be } \\
\text { higher than the } 86 \text { Year } \\
\text { syllabus }\end{array}$ & \multirow{2}{*}{\multicolumn{2}{|c|}{$\begin{array}{l}\text { Emphasized the cultivation of } \\
\text { reading and writing }\end{array}$}} \\
\hline Writing & \multirow[t]{3}{*}{ Not mentioned } & A little writing & $\begin{array}{l}\text { Elementary } \\
\text { writing }\end{array}$ & $\begin{array}{l}\text { A certain amount of } \\
\text { writing }\end{array}$ & & \\
\hline Listening & & A little listening & $\begin{array}{l}\text { Elementary } \\
\text { listening }\end{array}$ & $\begin{array}{l}\text { A certain amount of } \\
\text { listening }\end{array}$ & \multirow{2}{*}{\multicolumn{2}{|c|}{ Emphasized listening and speaking }} \\
\hline Speaking & & A little speaking & $\begin{array}{l}\text { Elementary } \\
\text { speaking }\end{array}$ & $\begin{array}{l}\text { A certain amount of } \\
\text { speaking }\end{array}$ & & \\
\hline Translation & $\begin{array}{l}\text { Ordinary } \\
\text { translation }\end{array}$ & Not mentioned & $\begin{array}{l}\text { Students of the } \\
\text { sciences were } \\
\text { required to } \\
\text { translate texts }\end{array}$ & $\begin{array}{l}\text { A certain amount of } \\
\text { translation }\end{array}$ & \multicolumn{2}{|c|}{$\begin{array}{l}\text { Students' translating competence } \\
\text { should be cultivated and the } \\
\text { detailed requirements were listed }\end{array}$} \\
\hline Focus & \multicolumn{2}{|c|}{$\begin{array}{l}\text { On basic language knowledge and } \\
\text { grammar }\end{array}$} & On reading & On reading and writing & $\begin{array}{l}\text { Especially on } \\
\text { speaking, as } \\
\text { autonomous learnin } \\
\text { ability to use langu }\end{array}$ & $\begin{array}{l}\text { listening and } \\
\text { vell as their } \\
\text { gg ability and the } \\
\text { age }\end{array}$ \\
\hline $\begin{array}{l}\text { Teaching } \\
\text { approaches }\end{array}$ & \multicolumn{2}{|c|}{$\begin{array}{l}\text { Face-to-face teaching on reading, } \\
\text { words and grammar }\end{array}$} & $\begin{array}{l}\text { Teacher-centered } \\
\text { approach }\end{array}$ & Grade-teaching & $\begin{array}{l}\text { Shift from } \\
\text { multi-media teach } \\
\text { computer- or wet } \\
\text { teaching assisted } \\
\text { teaching software }\end{array}$ & $\begin{array}{l}\text { computer-based } \\
\text { ing in } 2004 \text { to } \\
\text { b-based English } \\
\text { with various }\end{array}$ \\
\hline Testing & \multicolumn{3}{|l|}{ Not mentioned } & Required to pass CET 4 & \multicolumn{2}{|c|}{$\begin{array}{l}\text { Tests were designed to evaluated } \\
\text { students' all-round ability to use } \\
\text { English and were suggested to run } \\
\text { at the intercollegiate or regional } \\
\text { level. National tests were } \\
\text { mentioned, but not required. }\end{array}$} \\
\hline $\begin{array}{l}\text { Teaching } \\
\text { materials }\end{array}$ & \multicolumn{2}{|c|}{$\begin{array}{l}\text { Standard textbooks for all colleges } \\
\text { and universities }\end{array}$} & \multicolumn{2}{|c|}{ Diversity began to appear, but not much } & \multicolumn{2}{|c|}{$\begin{array}{l}\text { Various kinds of textbooks with } \\
\text { different foci and targeted at } \\
\text { different levels, often supplemented } \\
\text { with lively online, web or visual } \\
\text { materials }\end{array}$} \\
\hline Evaluation & \multicolumn{4}{|c|}{ Summative assessment } & \multicolumn{2}{|c|}{$\begin{array}{l}\text { Both summative and formative } \\
\text { assessment }\end{array}$} \\
\hline
\end{tabular}

Note. This table is adapted from Zhang Weilei's Comparative Analysis of College English Syllabi---From the Ecological Perspective (2011). 
The most ostensible changes are as follows:

1). Vocabulary amount had been increased from 1400 words in 1962 to 4795 in 2007 (for the basic requirement).

2). The role of grammar and exam had been gradually weakened.

3). Five skills were given growing importance, among which listening and speaking were accentuated.

4). Students were required to acquire multi-competencies, such as communicative competence, autonomous learning and overall ability to use language.

5). Differences among students were taken into consideration.

6). Diversity in teaching approaches and materials were greatly encouraged in recent reforms.

7). Formative assessment was introduced and would enjoy increasing attention.

What deserves further addressing is the issuing of College English Curriculum Requirements (Trial Implementation) in 2004. Replacing the standard syllabus, Requirements (2004) marked a deviation from the past not only in name, but also in its contents, thus unveiled the college English reform initiated in 2003, becoming a watershed document. Since then, uniformity disappeared and differences among students were recognized and taken into consideration. Since then, no universal standard would apply to all students in teaching requirements, teaching objectives, teaching arrangement or time allotment as well as exam and vocabulary amount. For the first time, the gap between regions and colleges and universities was given attention to. It is stated clearly in Requirements (2004) that considering China's vast territory and varied conditions both in regions, colleges and universities, three levels of requirements were set forth, namely basic requirements, intermediate requirements and advanced requirements, each setting different standards in listening, speaking, reading, writing and translating. All college students had to at least meet the basic requirements, whereas the other two targeted those whose English proficiency was higher. In Requirements (2004), listening, speaking and translating were particularly emphasized, the role of computer technology was introduced and the combination of both summative and formative assessment was recommended in evaluating students' learning, which were all new concepts unmentioned before, thus contributed to more modern, pragmatic and scientific curriculum requirements. Besides, colleges and universities began to enjoy autonomy in formulating their own respective CE teaching documents with reference to Requirement (2004).

The 2007 version of Requirements symbolized the deepening of college English reform. It maintained the rationale and major contents of the 2004 version, but was tuned up a little bit in some aspects. In teaching requirements, it set higher standard: in basic requirements, listening speed was raised from 130 words per minute to 150 words, reading speed was from 70 words per minute to 90 words, translating speed was from 300 words per hour to 350 words from English to Chinese and from 250 words to 300 from Chinese to English. In course design, rather than promoting computer- or web-based English software teaching, it proposed developing computer- and Web- based courses by teachers themselves and encouraged the extensive use of advanced information technology in teaching. In teaching model, it called for a shift from a teacher-centered pattern to a student-centered pattern, freeing students from the constraints of time or place and advocated students' individualized and autonomous learning and lifelong education concept to be cultivated among students. In evaluation, the definition of formative assessment and how to evaluate teachers' performance were supplemented. Finally, in teaching administration, students' credits acquired via computer-based courses should account for no less than $30 \%$ of the total credits in CE learning and teachers' development was proposed to be established. These revisions and modifications in the 2007 version offered CE reform a clearer direction and better accommodated students' needs and social and economic development as well.

\section{The Guidelines for College English Teaching (Exposure Draft)}

Ten- year CE reform has witnessed some progress. According to the English Proficiency Index (EPI) report by Education First (EF) (2014), China achieved a 2.53\% increase in proficiency during the 2007-2014 period. Successful undertakings of international events during this period, such as the annual trade fair for Association of Southeast Asian Nations (ASEAN), the 2008 Olympic Games in Beijing, the 41st World Exposition in Shanghai and the 16th Asian Olympics in Guangzhou, all provided a practice field for students, and the positive comment from the world was a living proof of the achievements CE has made. Between 2009 and 2010, an overall investigation was conducted among 530 universities by Foreign Language Education Committee of Higher Education under the Chinese Ministry of Education. This investigation provided a clear picture of the achievements college English has made. Among them are (1) students' listening and speaking was improved significantly, (2) the concept was widely accepted among students of enhancing students' ability to use English in a well-rounded way and to improve their general cultural awareness, (3)progress was made in curriculum design 
and both compulsory and optional courses were set up, (4)teachers began to recognize the importance of web-based courses, (5) formative assessment was carried out in evaluating students' English performance across China gradually (S. Wang \& H. Wang, 2011).

Admittedly, problems exist and CE is brought under question, challenge and scrutiny again and again. To name a few, teaching contents in CE overlap with those in senior school study, time-consuming but low-efficient CE learning results in students' demotivation and sluggishness in English classes, disqualification of teachers deprive students of enthusiasm in English study (Cai, 2011). Besides, when students' English level is generally thought to be higher than before (Cai, 2011), China was unsatisfactorily ranked as a low English proficiency country at 37th, far behind Malaysia, India and Japan in the 2014 EF EPI report. What has gone wrong? Can CE satisfy students' needs in study and at work both now and in the future? How should the CE reform be deepened?

To meet these challenges, Guidelines for College English Teaching (Exposure Draft) was formulated and submitted to the Ministry of Education for approval in early spring in 2015. Based on ten-year reform experience, grounded on the data collected over 530 colleges and universities across China, researchers, teacher educators, professors and scholars in Chinese ELT spent over two years in incubating Guidelines. It is a 20-page long document, providing guidance and reference for CE teaching reform. Guidelines elaborates on eight sections, namely, course orientation and nature, teaching objectives and requirements, course designing, evaluation and testing, teaching approaches and methods, teaching resources, teaching administration and teacher development. The following table offers an overview of Guidelines.

Table 2. Guidelines for College English Teaching (2015)

\begin{tabular}{|c|c|}
\hline \multicolumn{2}{|c|}{ Guidelines for College English Teaching (2015) } \\
\hline $\begin{array}{l}\text { Course orientation and } \\
\text { nature }\end{array}$ & $\begin{array}{l}\text { An integral part of higher learning, with both instrumentality and humanity; } \\
\text { A required basic course for undergraduates which serves the needs of students' individual development }\end{array}$ \\
\hline $\begin{array}{l}\text { Teaching objectives } \\
\text { and requirements }\end{array}$ & $\begin{array}{l}\text { To cultivate students' language use ability, to enhance their intercultural awareness and communicative capability, } \\
\text { to develop students' autonomous learning capability to meet their needs in their future study, life, job and } \\
\text { communication; } \\
\text { Three levels of objectives: basic, improving and developing }\end{array}$ \\
\hline Course designing & $\begin{array}{l}\text { General English, English for Special Purposes and Intercultural courses with both required and elective courses } \\
\text { that correspond to the needs from three-level objectives }\end{array}$ \\
\hline Evaluation and testing & $\begin{array}{l}\text { To combine summative assessment focusing on the result of the curriculum with formative assessment focusing on } \\
\text { promoting curriculum development; } \\
\text { to develop a testing system which includes both summative tests and formative tests favorable to cultivating } \\
\text { students' higher English proficiency }\end{array}$ \\
\hline $\begin{array}{l}\text { Teaching approaches } \\
\text { and methods }\end{array}$ & $\begin{array}{l}\text { to adopt task-based, collaborative, project-based and inquiry-based methods and approaches flexibly to enlighten } \\
\text { and inspire students based on their needs and differences in order to improve teaching and learning efficiency, to } \\
\text { achieve the transformation from teaching to learning, from passive learning to active learning, from focusing on } \\
\text { teaching objective to learning needs; } \\
\text { to employ extensively modern information technology in CE teaching and to promote transformation in teaching } \\
\text { ideology, teaching contents and teaching approaches, to further integrate curriculum teaching with the latest } \\
\text { information technology }\end{array}$ \\
\hline Teaching resources & $\begin{array}{l}\text { To make full use of modern information technology to extend the space and time of learning, to develop } \\
\text { high-quality textbook and to construct interactive, open and coordinative teaching platform to facilitate students' } \\
\text { autonomous learning }\end{array}$ \\
\hline $\begin{array}{l}\text { Teaching } \\
\text { administration and } \\
\text { teacher development }\end{array}$ & $\begin{array}{l}\text { To establish a sound three-tier (university-school-department) administration system and to encourage teachers to } \\
\text { carry out teaching-related research to fulfill their personal and professional development }\end{array}$ \\
\hline
\end{tabular}

Note. This table is based on Guidelines for College English Teaching (Draft Exposure) (2015).

From the table above, we can see the following three features in it: 


\subsection{Integration of Instrumentality and Humanity}

Instrumentality of English-as-a-tool is universally acknowledged and reinforced by each version of the English curriculum syllabus (Adamson, 2004), but only Guidelines states clearly and emphatically its integration with humanity. In its 2004 year version, CE was defined as "a language course that provides basic knowledge about English, but also a capacity enhancement course that helps students to broaden their horizon and learn about different cultures in the world" (2004 version). The 2007 year version added by saying "It not only serves as a tool, but also has humanistic values" and suggested considering the development of students' cultural capacity and the teaching of knowledge about different cultures in the world (2007 version). But further explanation on quality education or humanistic values was missing.

Differently, Guidelines (2015) states explicitly in the course nature part for the first time that "College English has both instrumentality and humanity". Besides, it goes on to explain that instrumentality is mainly embodied in English for General Purposes (EGP) (focusing on enhancing students' five language skills) and English for Specific Purposes (ESP) while humanity is in intercultural education. Furthermore, in course design part, Guidelines offers guidance on the design of three modules of courses: EGP, ESP and Intercultural Courses, including their time allotment, teaching objectives, teaching contents, foci, methods and suggested courses.

Guidelines' humanity is mainly reflected in the student-centered ideology which is implemented throughout Guidelines. Student-centered ideology means abandonment of standard criterion and teacher-centered pattern, but at the same time empowering colleges and universities, teachers and students to cooperate with each other in the teaching-learning-assessing-learning process. In its eight sections, Guidelines shows deep concern for students and offers details in how to cater to students' needs by offering them different courses and setting varied objectives for students from different regions, social classes and ethnic groups. In testing and evaluation section, it is strongly recommended that each college and university should make use of information technology to track and collect data about students' learning, to establish students' portfolio and analyze students' learning characteristics in order to offer corresponding feedback and evaluation. It is also advised that teacher-student communication should be enhanced. With this ideology, a diversified and individualized curriculum system is expected to be formed.

\subsection{Intercultural Education}

The introduction of intercultural education in Guidelines also manifests its humanity. Intercultural education was a new concept in the official documents about CE in China. It was officially introduced at the 43rd Session of International Conference on Education held by UNESCO. In the document The contribution of education to cultural development (1990), intercultural education was defined as the affirmation of each culture within its own set of rules and its receptiveness to other cultures, with a view to the construction of a common new civilization. It includes two aspects, one being an understanding of the culture of other countries, and the other an understanding of the cultures of different ethno-cultural groups within the same country. The aim of intercultural education is to train individuals not only to understand different cultures but to engage in intercultural communication (1992). According to this document, intercultural teaching in schools should set up, but not be confined to one or more additional courses on intercultural subjects, such as the history of civilization, cultural anthropology or an introduction to minority cultures, or even to organizing formal or out-of-school activities connected with those subjects (1992).

The mentioning of intercultural education in Guidelines signals the beginning of intercultural education in CE teaching in China. Accordingly, colleges and universities can set up different courses targeted at this aim, such as Chinese Civilization, Western or European Civilization, Chinese and Western Philosophy, Cross-cultural Communication, the Study into Chinese Ethnic Groups and American Culture, to mention some. Besides, we can expect intercultural exchange activities will be carried out soon on Chinese campuses, such as exchange study programs, culture tours or pen-pal activities. The introduction of intercultural education not only integrates instrumentality with humanity, but helps achieve its educational purpose, that is, to develop individuals aesthetically, morally and scientifically.

\subsection{Three Modules of Course Design for Three Levels of Teaching Objectives}

Oriented by English use in reality, multiple course design for multiple teaching objectives reflects concern for students and shows respect for students' individuality, thus contributing to a more diversified English teaching curriculum. Taking into full consideration the gap between regions, social classes and ethnic groups due to their varied access to educational resources (Feng, 2009), Guidelines accordingly offers three English curriculum modules for three levels of teaching objectives, namely, basic, improving and developing ones, thus forming an open and dynamic multiple teaching objective and curriculum system. 
Basic objectives are mainly for ethnic group students and students from remote and poor regions or students with low English proficiency, aimed at reinforcing and enhancing their language knowledge and skills. At the end of the study, students should increase another 2000 words, with 400 related to their future jobs or major, and should be able to have basic oral and written communication ability.

Improving objectives are for the majority of students, aimed at enhancing their language ability and communication ability. Students should increase 3000 words, with 600 related to their major or future jobs, should be able to analyze discourse structure, comprehend the logic of texts and be fluent and efficient in their oral and written communications.

Developing objectives are for a small number of students who have a high proficiency in English and a higher demand on English learning. After study, they are expected not only to be able to communicate well on major-related topics, but also learn how to analyze, synthesize and compare information from different sources in order to form ideas.

To help them achieve these respective goals, three modules of courses are designed to cater to students' different needs. They are EGP courses, ESP courses and Intercultural courses. These three modules can be compulsory or optional and the corresponding specific courses needed to be decided by each college and university according to their students' needs.

The following chart offers us a glimpse of the suggested courses for students at three different levels.

Table 3. Curriculum design for Guidelines (2015)

\begin{tabular}{|l|l|l|l|}
\hline Objectives & EGP & ESP & $\begin{array}{l}\text { Intercultural courses } \\
\text { (for reference) }\end{array}$ \\
\hline Basic & 1.5 years & EGAP & $\begin{array}{l}\text { Hidden curriculum that offers introductory information } \\
\text { about Chinese and western cultures }\end{array}$ \\
\hline Improving & 1 year & EAP, ESP \& EOP & $\begin{array}{l}\text { Intermediate Cultural courses: movie appreciation, } \\
\text { public speaking, introduction to European civilization/ } \\
\text { English-speaking countries, Chinese culture etc. }\end{array}$ \\
\hline Developing & $0.5-1$ year & EST, EBE, ESS etc. & $\begin{array}{l}\text { Advanced cultural courses: English Poetry, Literature, } \\
\text { cross-cultural communication, Shakespeare plays, etc. }\end{array}$ \\
\hline
\end{tabular}

Note. This table is based on Guidelines for College English Teaching (Draft Exposure) (2015).

(EGP: English for General Purposes; EGAP: English for General Academic English for Science and Technology; EBE: English for Business and Economics; ESS: English for Social Sciences).

\section{Challenges for Teachers and Solutions}

The issuing of Guidelines signifies a new round of CE reform. It is stately in Outline of the national medium and long-term education reform and development plan (2010-2020) (Outline) that the core task of higher education is to improve its teaching quality (2010: 3). As an integral part of higher education, it is also required to improve CE teaching quality. As Outline writes in its beginning, national development is based on education and education is decided by teachers. To improve teaching quality, it is necessary to improve teachers' quality as they are the implementers of new ideas and the agents for any change. Therefore, it is consistently stated in Guidelines and its predecessors that increased teachers' quality and capabilities are key to teaching quality improvement and CE curriculum construction (2004: 7, 2007: 9, 2015: 19-20).

The three new features manifested in Guidelines raise higher demands on teachers' professional and teaching capabilities, thus pose substantial challenges to CE teachers. Of all the challenges confronting teachers, the most prominent is the demand on college English teachers' professional expertise. Of various definitions of Chinese $\mathrm{CE}$ teachers' professional expertise, English proficiency and subject knowledge are universally acknowledged to be its basic constituents. Increasingly higher level of students' English and the new objectives elaborated in Guidelines require CE teachers to improve their own English proficiency as well as their thinking and reflecting 
ability. ESP and intercultural courses set even higher demands on teachers. On one hand, they need to equip themselves with related subject knowledge and keep updating their information, on the other hand, they have to pay attention to their teaching methods and skills. Otherwise it can easily fall into the traditional teacher-centered teaching pattern which bores students. But because of heavy teaching load and insufficient knowledge in ESP, college English teachers may feel incapable of developing their professional expertise. Based on the recent survey of 428 colleges and universities across China, the average teaching load is 13.5 hours per week (S. Wang \& H. Wang, 2011).

Another challenge comes from the employment of information technology in course design. Computer-based English teaching in China has experienced computer-assisted instruction (CAI) and computer-assisted learning (CAL) stage and is experiencing information technology and curriculum integration (ITCI), yet English teachers' computer or information competence is far below the standard set by UNESCO (He, Pan, \& Liu, 2015). Technology cannot replace teachers, but teachers with computer technology will replace those without. The status quo of college English teachers' computer competence remains a big concern and turns the design and the development of high-quality web-based teaching resources an issue in the air. How to keep pace with the times and update teachers' information technology remains a severe challenge. Still, the transition to ITCI requires all teachers to further liberate their view of language learning and teaching from a knowledge-oriented one to a competence-oriented one and better understand and quicken their role shift from the traditional knowledge transmitter to a multi-role educator.

The demand on academic performance poses a third austere challenge. According to Wang's survey into 467 colleges and universities across China, $80.1 \%$ of 21,050 college English teachers are women who dominantly assume the homecare-taker role. Besides, the average 13.5 teaching hours, large class size, additional class-preparation and homework-checking time plus the most serious problem, insufficient knowledge of research methods and research theories, rendered most of the college English teachers helpless and hopeless in doing research. Due to the reform in previous years, the percentage of doctor and master degree holders among CE teachers increased nationwide from $1.2 \%$ and $21.9 \%$ in 2001 to $1.5 \%$ and $60.1 \%$ respectively in 2010 , but it is far below the percentage in other subject disciplines (Wang, 2011). College English teachers feel incapable in doing academic research, publishing academic papers and applying for research projects.

All these and other unmentioned challenges bring insecurity and huge emotional and professional pressures to college English teachers, making them vulnerable and impotent. They not only have to accommodate new ideas, new roles and new environment, but to teach with limits and to satisfy different demands from the curriculum, the university and students.

\section{Solutions}

Therefore, to help develop teachers professionally and successfully, teacher education consciousness and efforts from three levels are indispensable. Firstly, college English teachers should cultivate life-long education and self-directed development consciousness, which is the prerequisite. This is an era full of changes. He/she who does not keep updating ideas and knowledge will be abandoned eventually. Therefore, college English teachers should keep reminding themselves to learn and improve themselves in an all-rounded way. Self-directed development consciousness is a responsible attitude and the driving force to personal professional development. Without this consciousness, learning is passive and painful and efficiency can be low. With this consciousness, teachers will become self-directed learners. They will become aware of their needs and orientation in development, align their personal development with their professional development and take the initiative in searching opportunities of and making efforts in learning. Thus, learning becomes active, yields positive results and brings enjoyment. The earlier college English teachers develop this consciousness, the more motivated they will become and more willing to invest time and energy in self-development. In one word, life-long learning and self-directed development consciousness can help teachers become more confident in handling challenges from life, study and work and make the changes in teaching and learning possible.

Secondly, the faculty and the university should offer support and help in college English teachers' professional development by setting up corresponding teacher education system. In-service professional training workshops, seminars and lectures should be held regularly in order to upgrade teachers' professional expertise and computer skills and update teachers' information of the latest development in relevant research areas and foreign language education both at home and abroad. Community of practice should be encouraged to set up among teachers so that activities related to teaching and researching can be carried out to help teachers learn from and collaborate with each other. By establishing in the community apprenticeship between the seasoned teachers or researchers and the novice teachers can both promote each other to achieve prosperity in career. Degree-promotion plan can 
be carried out to encourage teachers to further their study both at home and abroad. Teachers should be motivated to acquire master and doctoral degrees in other subjects, such as mass media, marketing, accounting and logistics in order to offer qualified teachers in EAP and ESP teaching.

What's more, CE teachers should be inspired to reflect on their teaching, to raise queries from teaching and carry out research in teaching. In this way, teaching and research can integrate and facilitate each other well. Action research is an efficient way to improve teaching and make achievements academically. By analyzing the problems in the practice of language teaching and evaluating the process of teaching from the perspective of a researcher, CE teachers can transit smoothly and successfully from technician-teacher to research teacher. With improved professional expertise and well-rounded quality development can teachers enhance their sense of achievements and teaching quality by engaging and helping students attain their objectives.

Thirdly, the government should continue their support in teacher education programs in CE and offer favorable policies to foster success in these programs. Each year the Ministry of Education issues a large sum to support or entrust tertiary teacher education institutions to provide English language teacher education programs. For example, Foreign Language Teaching and Research Press and Shanghai Foreign Language Education Press are the two most renowned foreign language publishing presses in China which exert wide-spread influence in college English education. Annually the two presses make use of national educational funds or self-raised funds to hold teaching competitions, training programs, workshops and seminars in college English teaching education which have benefited thousands of teachers across China. Although promoting their teaching and learning resources is one of their principal purposes, those training activities have helped introduce to CE teachers in China new ideas, pedagogical innovations, more efficient assessing methods and the latest trends in research. Besides, the government should set up MA or EDD or similar promotional programs to help aspiring teachers to improve themselves academically and professionally. Different from the national official matriculation of these programs, the promotional plan can lower its threshold to some degree and make use of distance learning or summer and winter holidays to offer courses. Furthermore, collaboration between China and foreign countries in English teacher education should be encouraged and established.

\section{Conclusion}

In the article, an overall review of all the CE curriculum syllabi is presented since its establishment in the 1950s. Comparisons among them showcase successes in CE teaching in China. But social and economic developments require more innovations. Against this backdrop Guidelines offers college English a new direction in its transitional phase.

Different from previous syllabus, Guidelines for College English Teaching (Exposure Draft) presents three new ideas. It not only stresses the integration of instrumentality with humanity of $\mathrm{CE}$, but for the first time illuminates clearly how these two features can be embodied in its course design. Besides, humanity permeates every section of Guidelines. The introduction of intercultural education ushers in the beginning of intercultural education in $\mathrm{CE}$ teaching in China and contributes to the diversity of course design. The open and dynamic system of curriculum design for multiple teaching objectives rejuvenates $\mathrm{CE}$ and pushes $\mathrm{CE}$ to move forward more confidently and affirmatively.

This article also brings to the fore challenges and difficulties Guidelines poses to CE teachers. The priority is the improvement of professional expertise of CE teachers, without which any change or reform cannot be achieved. The employment of computer technology and the increasing demand on academic performance plus personal limitations makes CE teachers feel insecure, vulnerable and incapable.

To help CE teachers cope with these pedagogical, professional and psychological challenges, suggestions are proposed from personal, faculty and university as well as government level. The prerequisite is the cultivation of life-long education and self-directed development consciousness. With the fulfillment of this prerequisite, support from faculty, university and government is worthwhile and significant. Only in this way can CE teachers have the possibility to achieve the goal stated in Guidelines and promote further advancement in CE.

What is lacking in Guidelines lies in three aspects according to my personal understanding. One is a more meticulous division of language capabilities is needed. China is a vast country with a huge population of university students at various levels of English proficiency. Three levels are not enough to measure the capabilities of all college and university students. The second is the construction of overall integrity and system of syllabi in English learning from elementary to university. Right now all these syllabi are independent from each other and the situation of fragmentation limits the efficiency and quality of language learning and teaching to a great degree. Hopefully, a framework similar to Common European Framework of Reference for Languages: Learning, Teaching and Assessment (CEF) will be released in near future to provide a common foundation for 
English teaching in China. The third is the consideration of providing more open evaluating approaches. Internationally recognized tests such as TOEFL and IELTS should be integrated into the evaluation system.

\section{Acknowledgment}

This article is part of the research result of the project entitled Exploration into College English Teachers' Professional Development in the Context of Educational Reform sponsored by Guangdong University of Foreign Studies to whom I extend my most sincere thanks.

\section{References}

Adamson, B. (2004). China's English: A history of English in Chinese education (pp. 135-173). Hongkong: Hongkong University Press.

Bryan, K. S., Tracy, E. Z., \& Allison, R. B. (2010). Syllabus detail and students' perceptions of teacher effectiveness. Teaching of Psychology, 37,186-189. http://dx.doi.org/10.1080/00986283.2010.488523

Cai, J. (2011). A way out for EFL at Tertiary Level Education in Mainland China. Shanghai Jiaotong University Press: Shanghai.

Chinese Ministry of Education. (1985). College English syllabus (for students of sciences and engineering). Beijing: Higher Education Press.

Chinese Ministry of Education. (1986). College English teaching syllabus (for students of arts and sciences). Shanghai: Shanghai Foreign Language Education Press.

Chinese Ministry of Education. (1999). College English teaching syllabus (for students of arts and sciences). Shanghai: Shanghai Foreign Language Education Press.

Chinese Ministry of Education. (2004). College English curriculum requirements (for trial implementation). Beijing: Tsinghua University Press.

Chinese Ministry of Education. (2007). College English curriculum requirements. Beijing: Foreign Language teaching \& research Press.

Chung, H.-S., \& Kim, J.-M. (2014). Semantic model of syllabus and learning ontology for intelligent learning system. Lecture Notes in Computer Science, 175-183. http://dx.doi.org/10.1007/978-3-319-11289-3_18

Dublin, F., \& Olshtain, E. (1986). Course desgin. Cambridge: Cambridge University Press.

EF EPI Report. (2014). from https://en.wikipedia.org/wiki/EF_English_Proficiency_Index

Feng, A. W. (2009). English in China: Convergence and Divergence in Policy and Practice. In L. Lim, \& Ee-ling Low (Eds.), AILA Review 22: Multilingual, globalizing Asia: Implication for policy and education (pp. 85-102). http://dx.doi.org/10.1075/aila.22.07fen

Fu, K. (1986). Educational history of Chinese English. Shanghai: Shanghai Foreign Language Education Press.

He, C., Pan, C., \& Liu, L. (2015). An Investigation into university foreign language teachers' information competence and the study into the strategies of its cultivation. Journal of Daqing Normal University, 35(3), 132-137.

Hu, G. (2005). Reforms of Basic English-language education in China: an overview. International Journal of education reform, 14(2), 156.

Liu, Y. (2015). Foreign Language Education Planning in China since 1949: A Recurrent Instrumentalist Discourse. Working Papers in Educational Linguistics, 30(1), 75.

Outline of the national medium and long-term education reform and development plan (2010-2020). (2010). Beijing: the Ministry of Education.

Wang, S., \& Wang, H. (2011). An investigation into the current situation of College English teaching among colleges and Universities in China and its reform and developing directions. Chinese Foreign Languages, $8(5), 4-10$.

UNESCO. (1992). The contribution of education to cultural development. Retrieved from http://www.researchgate.net/publication/234724829_Intercultural_Education_for_Cultural_Development_T he_Contribution_of_Teacher_Education

Wang, S. (2012). Faculty development in the process of college English course system. Foreign Languages, $151(4), 5$. 
Wilkins, D. A. (1981). Notional Syllabus. London: Oxford University Press.

Zhang, W. (2011). Comparative Analysis of College English Syllabi -From the Ecological Perspective. Modern Education Science, 8(3), 149-150

\section{Copyrights}

Copyright for this article is retained by the author(s), with first publication rights granted to the journal.

This is an open-access article distributed under the terms and conditions of the Creative Commons Attribution license (http://creativecommons.org/licenses/by/3.0/). 